\title{
Impact of excess cement removal on vertical misfit and cement line quality in onlays
}

Impacto da remoção do excesso de cimento sobre desadaptação e qualidade da linha de cimento em onlays
Matteo Baiotto SOARES

DDS - MS - Graduate Student - Division of Dental Prosthetics Dental Research Center São Leopoldo Mandic - Campinas - Brazil.

Ricardo Tatsuo INOUE

DDS - MS- PhD - Professor - Division of Dental Prosthetics - Dental Research Center São Leopoldo Mandic - Campinas - Brazil.

Lucas Zago NAVES

DDS, MS - Graduate Student - Department of Restorative Dentistry - Piracicaba Dental School -Piracicaba - Brazil.

Janisse MARTINELLI DDS - MS - PhD - Professor - Restorative dentistry Division Uberaba University - Uberaba - Brazil.

Luciano de Souza GONCALVES

DDS - MS - PhD - Professor - Restorative dentistry Division Uberaba University - Uberaba - Brazil.

\section{Abstract}

Aim: To evaluate vertical misfit and cement line quality of onlays cemented with resin luting cements using two different methods for removal of excess cement. Materials \& Methods: Lithium di-silicate restorations were fabricated and cemented at 24 human molars that received onlay type preparations. The specimens were randomly divided in two groups $(\mathrm{n}=12)$ : Group 1 (G1) where cement excess was removed at pre-gel stage and Group 2 (G2) with cement excess was removed after polymerization. Vertical misfits measurements at cement line were performed twice, before and after cementation. Epoxy resin replicas were obtained from the specimens and cement line quality was analyzed with a scanning electron microscope before and after the finishing and polishing procedures. The replicas were also classified according to their condition in unsatisfactory, acceptable or good. Vertical misfits values were submitted to Student test $(p<0.05)$ and the quality line data were analyzed with Mann-Whitney for independent samples $(\mathrm{p}<0.05)$ and Wilcoxon test for paired specimens $(\mathrm{p}<0.05)$. Results: Vertical misfit and cement line quality presented no difference values to $\mathrm{G} 1(26.60 \pm 8.0)$ and G2 $(24.10 \pm$ 8.0). However, finishing and polishing procedures affect positively the cement line quality in both groups $(\mathrm{p}=$ 0.59). Conclusion: The cement excess removal methods had no influence on vertical misfit and cement line quality for restorations. Finishing and polishing procedures improved the cement line quality in both groups.

\section{KeYWORDS}

Lithium di-silicate; Partial fixed dental prosthesis; Vertical misfit.

\section{Resumo}

Objetivo: Avaliar adaptação marginal e a influência do polimento sobre a linha de cimentação de restaurações cerâmicas cimentadas com cimento resinoso utilizando duas formas dois métodos de remoção do excesso do cimento. Métodos: Foram fabricadas restaurações em cerâmica reforçada por dissilicato de Lítio e cimentadas à vinte e quatro molares humanos que receberam preparos protéticos tipo onlay. Os corpos de prova foram divididos aleatoriamente em dois grupos ( $\mathrm{n}=12)$ : Grupo 1 (G1) em que o excesso de cimento foi removido no estágio pré-gel e Grupo 2 (G2) em que o excesso de cimento foi removido após a polimerização. A mensuração da desadaptação marginal foi realizadas em doi momentos, antes e depois da cimentação. Réplicas em resina epóxi de todos os corpos de prova foram confeccionadas para avaliação da qualidade da linha de cimentação utilizando um microscópio eletrônico de varredura antes de depois dos procedimentos de acabamento e polimento e classificado como insatisfatório, aceitável e boas condições. Os valores de desadaptação foram submetidos ao teste $t \mathrm{te}$ Student $(\mathrm{p}$ $<0,05)$ e os dados de qualidade da linha de cimentação foram analisados pelo teste de Mann-Whitney para amostras independentes $(\mathrm{p}<0,05)$ e pelo teste de Wilcoxon para amostras pareadas $(\mathrm{p}$ $<0,05$ ). Resultados: A desadaptação marginal e a qualidade da linha de cimentação não apresentaram diferença significativa G1 $(26,60 \pm 8,0)$ e G2 $(24,10 \pm 8,0)$. Entretanto, os procedimentos de acabamento e polimento influenciaram positivamente a qualidade da linha de cimentação em ambos grupos $(p=0,59)$. Conclusão: $\mathrm{O}$ método de remoção do excesso de cimento não influenciou a adaptação ou a qualidade da linha de cimentação das restaurações cerâmicas. Os procedimentos de acabamento e polimento melhoraram a qualidade da linha de cimento nos dois grupos.

\section{Palavras-chave}

Dissilicato de lítio; Prótese parcial fixa; Desadaptação marginal. 


\section{INTRODUCTION}

The aesthetic of dental restorations is a major concern for patients and subject for the development of several new dental materials. Core ceramics for all-ceramic restorations presents a prominent position in aesthetic restorative dentistry, with excellent mechanical properties, biocompatibility and faithfulness reproduction of translucency, color degrees of dental structure[1-3] and less prone to bacterial adhesion [4]. However, dental preparation and cementation procedure will determine fracture strength, longevity, esthetics and adaptation of ceramics restorations $[2,5]$.

Cements characteristics as high wear abrasion strength, film thickness, and wettability affect the ceramic restoration success [6-8]. The maintenance of gingival health and longevity of a dental prosthesis have a closely relation to these marginal sealing [912]. The line cementation interface should receive careful attention from the clinician, because oral fluids and acid bacteria might promote dissolution of the cement agent, resulting in a worst gap quality $[13,14]$ that could be a crevice for bacteria biofilm accumulation promoting secondary caries and periodontal diseases, reducing the longevity of restoration $[12,15,16]$. Factors as: cementation thickness line, preparation teeth design, finish line angulations, selected restoration material and processing method are essential for the success of prosthetic treatments [17]. Furthermore, vertical misfit between prosthesis and teeth present an important criterion used on clinical evaluation of indirect restoration,[18] with acceptable misfits values until $120 \mu \mathrm{m}$ [19-20].

During an adhesive prosthetic cementation, the excess of the resin cement removal is required to achieve a smoother cement line. If this procedure is concluded after cement setting, grooves and roughness (due to material hardness) are produced, which enables bacteria adhesion, especially critical at the proximal faces at gingival or subgingival area [4,17,21-23]. Therefore, if cement excess was removed while the resin cement is capable to flow, a smoother surface could be achieved because the material could be removed using a spatula. In addition, is easier to remove non-polymerized cement form the proximal areal [21] reducing the chance of scratches formation on the restoration or tooth surfaces.

The purpose of this study was to evaluate vertical misfit and cement line quality of onlay pressed ceramic restoration according to technique of cement excess removal.

\section{Material \& Methods}

This study was approved by the Ethics Committee of the Dental School of São Leopoldo Mandic Dental Research Center, Campinas, under the protocol \#07/170 according to resolution 196/1.996 of Brazilian National Health Council at Health Ministry.

Twenty-four sound human third molars freshly extracted were selected and cleaned and their roots were embedded in P.V.C cylinders (Tigre, Joinville, SC, Brazil) with epoxy resin (Buehler Ltd, Lake Bluff, IL, USA). With conical diamond burs (Inoue/Zanetti/Feltrin Ref. 6727- KG Sorensen, São Paulo, SP, Brazil) in high speed cooled with air/water, onlay preparations were manually made with expulsive walls ( $6^{\circ}$ taper), rounded angles, margin in enamel and occlusal reduction minimal of $2 \mathrm{~mm}$, by only one operator (Figure 1).

All laboratory procedures were performed under controlled temperature and humidity $\left(23 \pm 2^{\circ} \mathrm{C}\right.$ and $50 \pm 10 \%$ ). After the onlay cavities preparation the impression was taken with polyvinylsiloxane material (Express - 3M ESPE, St. Paul, USA) using a dual-viscosity impression technique and reproduced in dental stone type IV Exadur (Polidental, Cotia, SP, Brazil) mechanically mixed under vacuum (Multivac 4 - Degussa Hüls, Hanau, Germany). In order to obtain a wax pattern, one layer of spacer (True Spacer - Talladium do Brasil, Curitiba, PR, Brazil) was applied on stone casts up to $1 \mathrm{~mm}$ from the preparation margin, the wax patterns were obtained with a casting wax $(\mathrm{GmbH}$ \& Co. KG, Ispringen, Germany). Dental prepares were sealed with a provisional restorative material eugenol-free (Villevie, Joinville, SC, Brazil) and samples were stored in distilled water at $5^{\circ} \mathrm{C}$ for 72 h. All the twenty-four Empress II (IvoclarVivadent, Schaan, Liechtenstein) ceramic onlays were fabricated from a heat-pressed ceramic procedure following manufacturer's instructions.

\section{Cementation methods}

Teeth preparations were randomly separated in two groups of 12 (Group 1 - G1 and Group 2 - G2), cleaned with a water and pumice-stone paste in low speed before cementation. Internal surface of ceramic onlay restorations were etched 
with hydrofluoric acid 10\% (Dentsply, Petrópolis/ RJ, Brazil) for $20 \mathrm{~s}$, rinsed with water for $30 \mathrm{~s}$, dried for $10 \mathrm{~s}$ and silanized and waited for $60 \mathrm{~s}$ (Monobond S Ivoclar-Vivadent), and subsequently dried with a vigorous stream of air. Enamel and dentine was respectively etched with $37 \%$ phosphoric acid gel (Villevie, Joinville/SC, Brazil) for 30 and $15 \mathrm{~s}$, rinsed with water for $30 \mathrm{~s}$ and gently dried with cotton pellet. Adper Single Bond 2 (3M/ESPE) adhesive system was applied in two consecutive layers according to manufacturer's recommendation and photo-activated for $10 \mathrm{~s}$ with halogen light unit XL 2500 (3M/ESPE) with an irradiation of 7 Joules irradiance, as measured according to a calibrated power meter (Ophir Optronics Ltd, Jerusalem, Israel). Onlay ceramics were cemented with resin cement RelyX ARC (3M / ESPE) shade A3. A $0.5 \mathrm{kgF}$ static load was applied for 2 min after the ceramic placement. For G1, the excess of resin cement was removed 5 min after cementation and before photo-activation, using a \#5 explorer. Photo-activation was performed for $60 \mathrm{~s}$ with halogen light unit XL 2500 (3M/ESPE) at each face of the restoration (buccal, lingual, mesial, distal, occlusal), under pressure. In G2, the excess of resin cement was removed with a scalpel blade \#12 mounted at a \#3 knife handle immediately after photo-activation, that occurred as described for $\mathrm{G} 1$.

\section{Measurement of vertical misfit}

The measurements of vertical misfit were performed at two periods, before (BC) and after cementation (AC). Before onlay surface treatment and cementation, the ceramic restorations were placed on their respective tooth and fixed with silicone-based thermoplastic glue dismissed at the occlusal surface (where measurements were not performed) in order to avoid displacement of the ceramic onlay. With the onlay restoration in position, with spherical diamond bur (1012, KG Sorensen), in a high speed under air/water cooling, four pair of points were made for each specimen at the tooth and onlay surface, highlighted with overhead projector pen in black (Figure 1).

Vertical misfit measurements were made using an STM microscope (Olympus Optical Co. Ltd. - Japan) with an accuracy of $-5 \times 10-1 \mu \mathrm{m}$ or $5 \times 10-4 \mathrm{~mm}$. Four measurements were made on each specimen $\mathrm{BC}$ and $\mathrm{AC}$ resulting in eight measurements for specimen.
After the cementation procedures specimens were stored for $24 \mathrm{~h}(100 \%$ relative humidity at $37^{\circ} \mathrm{C}$ ) prior to the measurements, and were made following the same parameters as previously described for $\mathrm{BC}$ measurements. The mean of vertical misfit values were calculated by 3 measurements of each specimens of $\mathrm{BC}$ from the mean of each specimens of AC. Vertical misfit average values of G1 and G2 were compared by $\mathrm{t}$-student test for independent samples $(\mathrm{p}<0.05)$.

\section{Cement line analysis on Scanning Electron Microscope (SEM)}

In order to analyze the quality of cement line, replicas in epoxy resin (Epothin Hardener and resin, Buehler, IL, USA) of each specimen were made. Replicas were sputter-coated with gold in a Denton Vacuum Desk II Sputtering device (Denton Vacuum, Cherry Hill, NJ, USA) and observed by SEM (LEO 435VP Carl-Zeiss) at 20X magnification. Cement line verifications were performed before and after polishment and evaluated by a single evaluator using the following score:

- (0) Unsatisfactory conditions - when exaggerated excess and/or gaps were presented;

- (1) Acceptable conditions - when few excess or gaps were produced;

- (2) Good conditions - no gaps or excess were present. Good adaptation without any kind of interface mismatched.

After the evaluation, restoration margins were finished and polished using diamond finishing bur 3139FF (KG Sorensen), in high speed under air/ water cooling and diamond paste $3 \mu \mathrm{m}$ granulation (KG Sorensen), using a silicon rubber point (Enhance - Dentsply) for $10 \mathrm{~s}$ in low speed. The tips were changed after used in six specimens. After finishing and polishing procedures, the specimens were ultrasonic cleaned in distilled water for $5 \mathrm{~min}$. New replicas were made and sputter-coated for the SEM as previously described. Comparison between G1 and $\mathrm{G} 2$ for resin cement excess removal was made using Mann-Whitney non-parametric test $(\mathrm{p}<0.05)$ for independent samples. The comparison between samples after and before finishing and polishing procedures were realized separately by the Wilcoxon non-parametric test $(\mathrm{p}<0.05)$ for paired samples. 


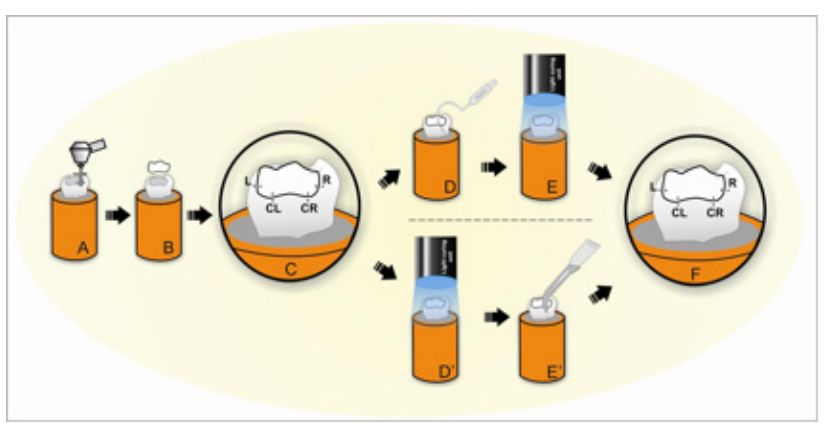

Figure 1 - Schematic illustration of specimen preparation. A- Tooth preparation in high speed cooled with air/water spray. B- Ceramic restorations positioned on their respective preparation. C- Vertical misfit measurement before cementation; letter $\mathrm{R}$ represents the distance between the margins of points on tooth and on ceramic restoration, both localized on right side. $\mathrm{Rc}$ is the distance between margins of points on tooth and on ceramic onlays on cervical margin at the right side. Lc is the distance between margins of points on teeth and on ceramics restoration on cervical margin at the left side and $L$ is the distance between the margins of points on teeth and on ceramics restoration, both on left side. D and E - Respectively G1- excess resin cement removal and the photo-activation. D' and E' - Respectively G2 - photo-activation and the excess resin cement removal. F- Measurement of vertical misfit before the cementation and the excess resin cement removal with the same parameters of previous measurement.

\section{Results}

Vertical misfit mean values between G1 and G2 are shown on Table 1 and no significant statistical difference was observed between groups in the t-student test for independents samples ( $p$ $<0.05$ ). Concerning the cement line evaluation, Mann-Whitney non-parametric test $(\mathrm{p}<0.05)$ for independent samples showed no significant statistical difference in cementation line quality between G1 and G2 groups (Table 2). However, the Wilcoxon test $(\mathrm{p}<0.05)$ presents that booth groups were positively influenced by finishing and polishing procedures (Table 3, Figure 2).

\section{Table 1 - Student t test $(P<0.05)$ Values for VERTICAL MISFIT.}

\begin{tabular}{c|c|c}
\hline Group & Vertical misfit $(\mu \mathrm{m})$ & $\mathbf{P}$ \\
\hline G1 & $26.60(8,0) \mathrm{A}$ & 0.23 \\
\hline G2 & $24.10(8,0) \mathrm{A}$ & 0.23 \\
\hline
\end{tabular}

Similar capital letters indicate absence of statistical difference.
Table 2 - Mann-Whitney test $(P<0.05)$ RESULTS FOR CEMENTATION LINE QUALITY.

\begin{tabular}{c|c|c|c}
\hline Groups & N & R & p \\
\hline G1 & 24 & 614 & 0.59 \\
\hline G2 & 24 & 562 & \\
\hline
\end{tabular}

( $n$ - Sample number. $\mathrm{R}$ - Score result).

\section{Table 3 - Wilcoxon $(P<0.05)$ test Results FOR GROUPS 1 AND 2.}

\begin{tabular}{c|c|c|c|c}
\hline $\mathbf{G 1}$ & $\mathbf{T}$ & pars number & $\mathbf{Z}$ & $\mathbf{p}$ \\
& 6 & 10 & -2.2424 & 0.025 \\
$\mathbf{G} 2$ & $\mathbf{T}$ & pars number & $\mathbf{Z}$ & $\mathbf{p}$ \\
& 0 & 8 & -2.5205 & 0.012 \\
\hline
\end{tabular}

Z-Scores.

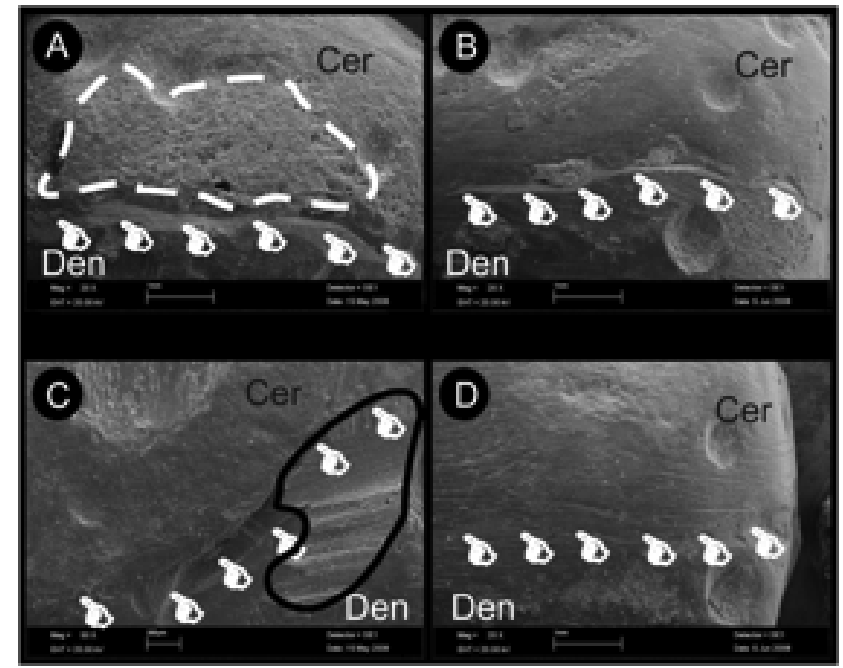

Figure 2 - SEM images of cement line for the G1 (A and $B)$ and $G 2$ ( $C$ and $D)$. Pointers in all images show cement line. In image $A$ the dotted line highlights the resin cement excess on the ceramic surface (Cer) and after finishing and polishing procedures a smoother surface can be seen (B). To G2 the black line (C) shows the grooves left by the scalpel blade on dentin (Den) and finishing and polishing procedures promoted the reduction of irregularities (D).

\section{Discussion}

The acceptable misfit limit for resin cementation is $120 \mu \mathrm{m}$, because low solubility of this cement type $[12,13,19,24]$. Several studies compared vertical misfits of crowns performed with IPS Empress2, Procera and In-Ceram systems. IPS Empress2 presented the lowest values, around $63 \mu \mathrm{m}[12,13,24]$ while the marginal misfit of ceramic restorations constructed with IPS Empress 2 and cemented with 
resin luting cement RelyX ARC showed satisfactory adaptation in this current study.

The vertical misfit values of this study (Table 1) are in agreement with the data of previous studies, in accordance to the clinical acceptance [23, 25]. At the Wolfart et al. [23] study using SEM, the vertical misfits values were from $96 \mu \mathrm{m}$ to $130 \mu \mathrm{m}$ to completed crowns, differing with the lowest misfits values found at the present study (Table 1). This probably occurs because the cement line on Total crown is localized in a hard anatomic region for cleaning. The concavity usually disrupts the removal of cement excess and we need to apply a higher load, what probably can induce a higher stress. The onlay conservative tooth preparation in the current study possibly favored the lower vertical misfit values. Chamfer finish line of the prosthetic preparation may also have contributed to minimize marginal misfit, producing adequate thickness to the placement of the restoration, improving the distribution of stress and the appearance of cracks [2].

To cementation line quality analysis, it was not found statistical differences for the tested groups, as shown in Table 2. This probably occurred because both techniques of excess removal of resin cement did not affect the position of the restoration, because they were carefully accomplished and partially polymerized. However, G1 was positively affected by finishing and polishing procedures (Figure 2), according to the results exhibited in Table 3 . The excess removal of resin cement before the photo-activation appeared allowed a more regular section promoting a smoother surface without failures left by the scalpel blade. In addition, the excess observed on the ceramic restoration and dental surface were removed, in part or completely after finishing and polishing. In this in vitro study, extracted teeth individually embedded in epoxy resin were used and there were no areas with difficult access, as proximal faces or under gingival margins. In the clinic situation, the resin cement removal excess before the polymerization using a \#5 explorer or a spatula could not be problematic, producing fewer scratches in areas where access of polishing methods is difficult.

Finishing and polishing procedures also had positive effect at the cementation line quality for G2 (Figure 2). At the moment of excess removal, the resin cement was rigid (after photo-activation), therefore the scalpel blade promoted grooves at the dental and ceramic surfaces. However, finishing and polishing procedures removed these defects partly or totally. Imperfections left at the cementation line, restorative material or dental surface can facilitate the bacterial biofilm adhesion, consequently an adequate excess cement removal and a judicious finishing and polishing steps are required for obtaining a smoother cementation margin [4,17,21-23] to avoid bacterial colonization, recurrent caries, periodontal disease $[15,16]$ increasing the longevity of ceramics restorations.

\section{Conclusion}

Based on the results of this study, it could be concluded that:

- The two different methods analyzed of resin cement excess removal did not affect the vertical misfit or the quality of the cementation line on onlay ceramic restorations.

- Both groups presented line cementation quality positively influenced by finishing and polishing procedure after cementation.

\section{Acknowledgments}

Authors are indebted to Dr. E.W. Kitajima, Dr. F.A.O. Tanaka and R.B. Salaroli (NAP/MEPAESALQ/USP, Brazil) for SEM equipment support and to Professor Lourenço Correr Sobrinho from Faculdade de Odontologia de Piracicaba (FOP/ UNICAMP). 


\section{REFERENCES}

1. Blatz MB. Long-term clinical success of all-ceramic posterior restorations. Quintessence Int 2002;33(6):415-26.

2. Giordano R, 2nd. A comparison of all-ceramic restorative systems: Part 2. Gen Dent 2000;48(1):38-40, 43-35.

3. Yilmaz H, Aydin C, Gul BE. Flexural strength and fracture toughness of dental core ceramics. J Prosthet Dent 2007;98(2):120-8.

4. Gemalmaz D, Ergin S. Clinical evaluation of all-ceramic crowns. J Prosthet Dent 2002;87(2):189-96.

5. Rosenstiel SF, Land MF, Crispin BJ. Dental luting agents: a review of the current literature. J Prosthet Dent 1998;80(3):280-301.

6. Della-Bona A. Characterizing ceramics and the interfacial adhesion to resin: II- the relationship of surface treatment, bond strength, interfacial toughness and fractography. J Appl Oral Sci 2005;13(2):101-9.

7. Frazier KB, Sarrett DC. Wear resistance of dual-cured resin luting agents. Am J Dent 1995;8(4):161-4.

8. Jacobsen PH, Rees JS. Luting agents for ceramic and polymeric inlays and onlays. Int Dent J 1992;42(3):145-9.

9. Dejak B, Mlotkowski A. Three-dimensional finite element analysis of strength and adhesion of composite resin versus ceramic inlays in molars. J Prosthet Dent 2008;99(2):131-40.

10. Quintas AF, Oliveira F, Bottino MA. Vertical marginal discrepancy of ceramic copings with different ceramic materials, finish lines, and luting agents: an in vitro evaluation. J Prosthet Dent 2004;92(3):250-7.

11. Sorensen JA. A rationale for comparison of plaque-retaining properties of crown systems. J Prosthet Dent 1989;62(3):2649.

12. Yeo IS, Yang JH, Lee JB. In vitro marginal fit of three allceramic crown systems. J Prosthet Dent 2003;90(5):459-64.

13. Boening KW, Wolf BH, Schmidt AE, Kastner K, Walter MH. Clinical fit of Procera AllCeram crowns. J Prosthet Dent 2000;84(4):419-24.

14. Mjor IA. Clinical diagnosis of recurrent caries. J Am Dent Assoc 2005;136(10):1426-33.

15. Bollen CM, Lambrechts P, Quirynen M. Comparison of surface roughness of oral hard materials to the threshold surface roughness for bacterial plaque retention: a review of the literature. Dent Mater 1997;13(4):258-69.

16. Quirynen M, Bollen CM. The influence of surface roughness and surface-free energy on supra- and subgingival plaque formation in man. A review of the literature. J Clin Periodontol 1995;22(1):1-14.

17. Ferrari M, Dagostin A, Fabianelli A. Marginal integrity of ceramic inlays luted with a self-curing resin system. Dent Mater 2003;19(4):270-6.

18. Goldin EB, Boyd NW, 3rd, Goldstein GR, Hittelman EL, Thompson VP. Marginal fit of leucite-glass pressable ceramic restorations and ceramic-pressed-to-metal restorations. J Prosthet Dent 2005;93(2):143-7.

19. Kokubo Y, Tsumita M, Kano T, Sakurai S, Fukushima S. Clinical marginal and internal gaps of zirconia all-ceramic crowns. J Prosthodont Res 2011;55(1):40-3.

20. McLean JW, von Fraunhofer JA. The estimation of cement film thickness by an in vivo technique. Br Dent $\mathrm{J}$ 1971;131(3):107-11.

21. Anami LC, Pereira CA, Guerra E, Assuncao e Souza RO, Jorge
AO, Bottino MA. Morphology and bacterial colonisation of tooth/ceramic restoration interface after different cement excess removal techniques. J Dent 2012;40(9):742-9.

22. Jung M. Finishing and polishing of a hybrid composite and a heat-pressed glass ceramic. Oper Dent 2002;27(2):175-83.

23. Wolfart S, Wegner SM, Al-Halabi A, Kern M. Clinical evaluation of marginal fit of a new experimental all-ceramic system before and after cementation. Int $\mathrm{J}$ Prosthodont 2003;16(6):587-92.

24. Sulaiman F, Chai J, Jameson LM, Wozniak WT. A comparison of the marginal fit of In-Ceram, IPS Empress, and Procera crowns. Int J Prosthodont 1997;10(5):478-84.

25. Stappert CF, Dai M, Chitmongkolsuk S, Gerds T, Strub JR. Marginal adaptation of three-unit fixed partial dentures constructed from pressed ceramic systems. Br Dent J 2004;196(12):766-70; discussion 760, quiz 780.

Received: 2012 Oct. 03 Accepted: 2013 Feb. 07

Corresponding author:

Luciano de Souza Gonçalves Adress: Rua Francisco Fava, 623 - Ap. 207 Cep: 38050-550 - Uberaba / MG. Phone: (34) 9155-9083. E-mail: goncalves1976@yahoo.com.br 